lichens and algae are virtually all that botanists of the high Antarctic have available for study. Systematics and cataloguing were the main preoccupations of the early workers. Ecological studies began in eamest with the International Geophysical Year and International Biological Programme Tundra Biome investigations, making use of new kinds of instrumentation and techniques. Nowhere have these studies been pursued more diligently than in the maritime sector of Antarctica by biologists of British Antarctic Survey. R. E. Longton, formerly of BAS and now in the Botany Department of Reading University, over two decades has contributed much to botanical fieldwork at both ends of the world, and established a world-wide reputation in bryology. He is one of a very few botanists qualified to write this book, and all polar ecologists will be glad that he has.

The book starts with reviews of polar topography, geological history, climate, soils, biogeography and the polar moss and lichen floras, followed by reviews of vegetation classification systems and growth forms. It hen deals in turn with environmental relationships, colonization ans succession, and vegetation patterns on the ground. There is a chapter on radiation and microclimate and one on the physiology of mosses and lichens, patterns of growth and phenology. The penultimate chapter is on energy flow, nutrient cycling and the environmental influences - mostly baleful - of man, his animal, chemical and mechanical introductions, and his generally destructive activities in polar habitats. The last chapter, a long one, covers reproductive biology, evolution and dispersion strategems of polar mosses and lichens.

In his final two pages the author concludes that polar cryptogamic floras in the main comprise species from warmer climates that are likely to have developed before polar regions were cold. Phenotypic plasticity and and ability to deal equally successfully with much or little water allowed them to occupy new niches when forest gave way to tundra, and to gain advantages over the lessadaptable flowering plants. A few species, some polyploid, appear to have evolved under polar conditions.

This is a good book, well produced and with clear illustrations. I would not buy it for its conclusions (particularly at the appalling price) but would find it essential for any future thinking or decision-making that involved the ecology of polar terrestrial flora. (Bemard Stonehouse, Scott Polar Research Institute, University of Cambridge, Lensfield Road, Cambridge CB2 1ER UK.)

\section{AGRICULTURE IN ARCTIC FINLAND}

THE SOCIAL IMPLICATIONS OF AGRARIAN CHANGE IN NORTHERN AND EASTERN FINLAND. Ingold, Tim (editor). 1988. Helsinki, Finnish Anthropological Society (Suomen Antropologisen Seuran Toimituksia 22). $156 \mathrm{pp}$, illustrated, soft cover. ISBN 951-95435-2-X.

This interesting study brings to English readers detailed information on recent developments in farming in Fin- land. Many rural communities have been fragmented as a result of industrialization, and this has resulted in serious social consequences. The book contains four essays by English-speaking social scientists, and a summary article by Professor W.R. Mead. For northern scholars the paper by the editor, Tim Ingold, dealing with changes in Salla on the borders of Sami territory, with a mixed economy of farming, forestry and reindeer management, is the most rewarding. There is also an interesting paper by Robert Jarvenpa on Suomussalusi in Kainuu, south of the Arctic circle and close to the USSR, analysing the production strategies of farmers and their wives. Richard Gould contributes an ethno-archaeological study of an abandoned sub-Arctic farming community which is compared with similar material from Canada. The volume is broadly empirical, and is a valuable addition to our knowledge of Finland. (Ian Whitaker, Simon Fraser University, Burnaby, British Columbia, Canada V5A 1S6.)

\section{BRIEF REVIEWS}

KING ISLAND TALES: ESKIMO HISTORY AND LEGENDS FROM BERING STRAIT. Kaplan, L. D. (editor). 1988. Fairbanks, Alaska Native Language Center and University of Alaska Press. $259 \mathrm{p}$, illustrated, soft cover. ISBN 1-55500-19-3. US $\$ 19.95$ plus $\$ 1.55 \mathrm{p}$ and $\mathrm{p}$.

A collection of stories and narratives told by nine native story-tellers, translated from tape recordings made in Nome, Alaska in 1983, under the auspices of the Eskimo Heritage Program of Kawerak Inc. Haunting, inconsequential tales, pleasantly illustrated with photographs and drawings.

LIST OF NORTHERN SPECIALISTS AT CANADIAN UNIVERSITIES: 3rd EDITION. ACUNS. 1989. Ottawa, Association of Canadian Universities for Northern Studie (Occasional Publications 14). 176 p, soft cover. ISBN 0-921-421-05-2.

Listings alphabetical by name, by institutions, by disciplines and by geographical specializations, of almost 800 individuals at 49 universities, involved in a wide range of northern studies from archacology to zoology.

HIGH ALTITUDE MEDICINE AND PHYSIOLOGY Ward, M.J., Milledge, J. S. and West, J. B. 1989. London, Chapman and Hall. 515 p, illustrated, hard cover. ISBN 0-412-29010-3. £50.00.

Written by three medical officers (surgeon, physician and physiologist) with wide experience of mountaineering, this book contains much that is relevant and interesting to polar-oriented medicine. It includes chapters on the cardio-vascular system, peripheral tissue physiology, exercise, sleep, nutrition and intestinal function, endocrine and renal systems, thermal balance, reactions to cold, vascular disorders, hypothermia, local cold injury, accidents, emergencies and anaesthesia, and practicalities of field studies. Expensive, but good reading for any polar station library; more readable and relevant than several recent polar medical compilations. 